\title{
PENGARUH BESARNYA JAMINAN TERHADAP PEMBERIAN KREDIT DI BANK BPR JAWA TIMUR (BANK UMKM JAWA TIMUR) CABANG MAGETAN TAHUN 2012/2013
}

\author{
Reni Fitriana \\ Mahasiswa Prodi Pendidikan Ekonomi IKIP PGRI Madiun
}

\begin{abstract}
Abstrak. Penelitian ini bertujuan untuk membahas pengaruh besarnya jaminan terhadap pemberian kredit di Bank. Jaminan tambahan untuk mengamankan kepentingan bank dalam penulisansumber kredit. Hak dan jaminan yang digunakan memberikan daya ke bank untuk mendapatkan pembayaran tersebut. Sampel dalam penelitian menggunakan sampel sampling dimaksudkan dengan mengambil data pelanggan atau nasabah dari BPR JAWA TIMUR (BankUMKM Jatim) Cabang Magetan. Dalam hal ini peneliti hanya membatasi untuk aplikasi dan mengukur jumlah jaminan pinjaman, sedangkan penelitian ini dilakukan antara Februari dan April, sedangkan pada analisis yang digunakan adalah korelasi (r). Berdasarkan tingkat hasil yang signifikan akan digunakan dalam analisis hipotesis dalam penelitian ini $(\alpha)=0,05$ r_Tabel dengan $\mathrm{df}=50-2=48$ adalah 0,279 sedangkan nilai $r$ XY $=$ 0,450724827 Dari hasil perhitungan statistik menunjukkan bahwa $\mathrm{r}$ XY $>\mathrm{r}$ _Tabel kemudian $\mathrm{H}$ o $\mathrm{H}$ a ditolak dan diterima. Kesimpulan dari pengujian hipotesis dengan analisis statistik bahwa "Ada pengaruh dari jumlah jaminan terhadap pemberian kredit di BPR JAWA TIMUR (Bank UMKM Jatim) Cabang Magetan".
\end{abstract}

Kata kunci : Jumlah agunan, kredit.

\section{Pendahuluan}

Perbankan merupakan suatu lembaga keuangan yang ada di Indonesia yang memiliki peranan penting bagi kelangsungan perekonomian Indonesia. Bank merupakan mitra dalam rangka memenuhi semua kebutuhan keuangan mereka. Bank dijadikan sebagai tempat untuk melakukan investasi, pengiriman uang, melakukan pembayaran atau melakukan penagihan. (Kasmir 2007: 1)

Peranan BPR dalam perekonomian Indonesia dapat dilihat dari skala usahanya. Bila melihat skala usaha, harus dikatakan bahwa BPR kurang efisien dibanding bankbank umum. Penyebabnya adalah kecilnya skala usaha dan kualitas SDM. Tetapi BPR memiliki kekuatan dalam hal likuiditas dibanding bank umum. Keunggulan BPR yang lainnya yaitu BPR tetap menjalankan fungsi utamanya secara seimbang, sekalipun perekonomian Indonesia dalam kondisi krisis. BPR dilihat dari segi permodalan juga lebih baik dari pada bank umum.

Keuangan mikro di Indonesia telah ada sejak akhir abad ke-19 dengan berdirinya Bank Kredit Rakyat dan Lumbung Desa. Kedua lembaga ini dibentuk untuk membantu petani, pegawai, dan buruh melepaskan diri dari lintah darat. Bank Kredit Rakyat ditingkatkan menjadi Bank Desa yang cakupan pelayanannya diperluas meliputi kegiatan usaha di luar bidang pertanian.

Keadaan ini berubah setelah keluarnya Undang-undang (UU) No. 7 Tahun 1992 tentang Perbankan yang menetapkan bahwa hanya ada dua jenis bank di Indonesia, yaitu Bank Umum dan Bank Perkreditan Rakyat (BPR). (Kasmir 2007 : 19).

Dalam hal ini Bank Perkreditan Rakyat melakukan kegiatannya berupa penghim- 
punan dana dari masyarakat dan hanya disimpan dalam bentuk tabungan dan deposito. Berdasarkan keputusan menteri keuangan RI No. 221/ KMK.017/ 1993 tentang BPR diyatakan bahwa BPR hanya dapat didirikan dan menjalankan usaha dengan izin menteri keuangan setelah mendengar pertimbangan Bank Indonesia dan untuk memberikan izin usaha BPR dilakukan dalam dua tahap :

(1) Persetujuan prinsip, yaitu persetujuan untuk melakukan persiapan pendirian BPR. Di mana untuk mendapatkan persetujuan ini, pemohon (sekurangsekurangnya salah seorang anggota direksi) mengajukan permohonan kepada Menkeu dengan tembusan kepada BI.

(2) Ijin usaha yaitu izin yang diberikan untuk melakukan usaha setelah persiapan pendirian BPR.

Pengaruh Besarnya Jaminan Terhadap Pemberian Kredit Di BANK BPR JAWA TIMUR(Bank UMKM Jawa Timur) Tujuannya Ingin mengetahui jaminan di Bank BPR JAWA TIMUR (Bank UMKM Jawa Timur) Cabang Magetan terhadap pemberian kredit.

Ingin mengetahui pemberian kredit di Bank BPR JAWA TIMUR (Bank UMKM Jawa Timur) Cabang MagetanIngin mengetahui pengaruh jaminan terhadap pemberian kredit di Bank BPR JAWA TIMUR (Bank UMKM Jawa Timur) Cabang Magetan

a. Menurut (Teguh Pudjo Mulyono, 2008 : 296) Jaminan kredit (coleteral) dalam perkreditan karena perbandingan sebab tetap menduduki posisinya yang penting, terutama dalam fungsinya untuk pengamanan apabila kredit yang diberikan tersebut mengalami kegagalan. Oleh karena itu tidaklah berkelebihan kiranya sekali lagi para analisis kredit untuk diminta kejelian dan ketelitian dalam penilaian barang - barang yang dijaminkan kepada bank. Dalam penilaian ini ada 2 sasaran pokok yaitu :
1) Untuk menilai ekonomis dari barang jaminan

2) Untuk menilai nilai yuridis dari barang jaminan yang bersangkutan

Kedua nilai/ persyaratan tersebut harus dipenuhi secara lengkap apabila jaminan yang akan diikat tersebut memang dutujukan sebagai alat pengamanan atas kredit yang diberikan. Maka telah diuraikan sebab-sebab kegagalan perkreditan teryata banyak juga diakibatkan oleh faktor-faktor nonbank teknis atau disebabkan oleh hal-hal di luar jangkauan kekuasaan perbankan. Situasi semacam ini akan sangat berpengaruh terhadap keberhasilan industri perbankan dalam melakukan usahanya di bidang perkreditan.

b. Pemberian kredit merupakan kegiatan utama bank, dan sekaligus merupakan sumber pendapatan untuk menutup biaya bunga yang dibayarkan kepada para deposan atau masyarakat penyimpan dana dan biaya-biaya operasional; sedangkan kelebihannya merupakan keuntungan bagi bank. Oleh karena itu, pemberian kredit merupakan kegiatan bisnis bagi bank, dan berada dalam lalu lintas bisnis bagi bank dan merupakan tot daden van beheeren, atau tindakan kepengurusan bagi direksinya.Karena bank tidak terlepas dari bentuk-bentuk kerawanan atau risiko, terutama dalam kegiatan pemberian kredit, asas yang paling penting adalah prinsip kehati-hatian atau prudential principle. Asas ini wajib diterapkan dalam rangka melindungi dana masyarakat yang dipercayakan kepada bank.

c. Penelitian ini mengambil tempat di BANK BPR JAWA TIMUR (Bank UMKM Jawa Timur) Cabang Magetan. Yang beralamat Jl. Raya Gorang-Gareng Maospati Kab. Magetan telepon/ fax (0351) 439910 / 438407 Magetan pada tahun 2013. Pemilihan lokasi dilakukan secara sengaja/ purposif untuk menge- 
tahui pengaruh besarnya jaminan terhadap penerimaan kredit di Bank BPR Jawa Timur (Bank UMKM Jawa Timur) Cabang Magetan. Hal ini dilakukan untuk memudahkan pendataan terhadap besarnya jaminan terhadap pemberian kredit.

\section{Metode Penelitian}

Teknik pengumpulan data yang digunakan dalam penelitian adalah Wawancara. Teknik wawancara dilakukan dengan dua cara, yaitu melalui tatap muka langsung dan melalui telepon. Teknik kedua yaitu Observasi Objek (benda) atau kejadiankejadian tanpa adanya pertanyaan atau komunikasi dengan individu-individu yang diteliti. Teknik ketiga yang digunakan adalah Dokumentasi untuk mengambil data-data internal dari suatu Bank. Populasi dalam penelitian ini adalah nasabah Bank BPR Jawa Timur (Bank UMKM Jawa Timur) yang berjumlah 50 orang.

Teknik pengambilan sampel yang digunakan dalam penelitian ini adalah purposive sampling dilakukan dengan cara mengambil subjek bukan didasarkan atas strata, random atau daerah tetapi didasarkan atas adanya tujuan tertentu. Teknik ini biasanya dilakukan untuk mengetahui besarnya jaminan dan pemberian kredit nasabah. Variabel bebas dalam penelitian ini adalah besarnya jaminan, variabel terikatnya pemberian kredit.

\section{Hasil penelitian}

Besanya jaminan

Dari 50 orang peminjam di Bank BPR Jawa Timur Cabang Magetan yang memiliki pinjaman diatas rata - rata statistik $\geq 2.5000$ adalah sebanyak 40 orang atau $95 \%$ dari 50 orang peminjam di Bank BPR Jawa Timur Cabang Magetan.

Hal ini dapat disimpulkan bahwa besarnya jaminan pada Bank BPR Jawa Timur terhadap pemberian kredit sangat baik.

\section{Pemberian Kredit}

50 orang peminjam di Bank BPR Jawa Timur Cabang Magetan yang memiliki pinjaman diatas rata - rata statistik $\geq 1447300$ adalah sebanyak 36 orang atau $72 \%$ dari 50 orang peminjam di Bank BPR Jawa Timur Cabang Magetan.

Hal ini dapat disimpulkan bahwa pemberian kredit pada Bank BPR Jawa Timur terhadap besarnya jaminan sangat baik.

\section{Analisis Data Penelitian}

Pada dasarnya hipotesis merupakan jawaban sementara dari suatu permasalahan, dan untuk membuktikan bahwa jawaban tersebut benar harus didukung dengan data maupun fakta yang dapat dipertanggung jawabkan. Oleh karena itu, dalam sub bab ini akan dilakukan pengujian atas hipotesis yang telah diajukan pada bab sebelumnya.

Diperoleh Nilai $r_{X Y}=0,451$, sedangkan $r_{\text {Tabel }}=0,279$ sedang besar F hitung $=27,175$, harga ini selanjutnya dikonsultasikan dengan harga $\mathrm{F}$ tabel, dengan didasarkan pada dk pembilang $=\mathrm{k}$ dan $\mathrm{dk}$ penyebut $=(\mathrm{n}-\mathrm{k}-1)$, dan taraf kesalahan yang ditetapkan sebesar 5\%, $\mathrm{dk}$ pembilang $=1$, dk penyebut $=48$, maka diperoleh harga $\mathrm{F}$ tabel $=4,03$.

\section{Penutup}

\section{Simpulan}

1. Besarnya jaminan di Bank BPR Jawa Timur Cabang Magetan mempunyai nilai minimum 1 , nilai maksimum 4 , dengan nilai rata-rata jawaban responden adalah sebesar 25.000 dengan standar deviasi 1.31320. Dari 50 orang peminjam di Bank BPR Jawa Timur Cabang Magetan yang memiliki pinjaman diatas rata-rata statistik $\geq 25.000$ adalah sebanyak 40 orang atau $95 \%$ dari 50 orang peminjam di Bank BPR Jawa Timur Cabang Magetan. Hal ini dapat disimpulkan bahwa besarnya jaminan pada Bank BPR Jawa Timur terhadap pemberian kredit sangat baik.

2. Pemberian kredit di Bank BPR Jawa Timur Cabang Magetan mempunyai nilai 
minimum 1.4, nilai maksimum 840, dengan nilai rata-rata jawaban responden adalah sebesar 1.447300 dengan standart devisiasi 1.432400 . dari 50 orang peminjam di Bank BPR Jawa Timur Cabang Magetan yang memiliki pinjaman diatas rata-rata statistik $\geq 1447300$ adalah sebanyak 36 orang atau $72 \%$ dari 50 orang peminjam di Bank BPR Jawa Timur Cabang Magetan

3. Hal ini dapat disimpulkan bahwa pemberian kredit pada Bank BPR Jawa Timur terhadap besaranya jaminan sangat baik. Koefisien korelasi yang menunjukkan angka 0,4507 dan berarti lebih dari $\mathrm{r}$ tabel yai tu0,279. Pengaruh yang positif ini menandakan bahwa jika jaminan yang diberikan oleh nasabah bernilai besar maka pihak Bank akan memberikan kredit yang lebih besar pula. Namun jika bank menilai jaminan yang diberikan bernilai kecil, Dengan diketahuinya koefisien korelasi (r) sebesar 0,4507 tersebut maka pengaruh antara kedua variable memiliki interpretasi yang sedang.

\section{Saran}

Adapun saran yang dapat dikemukakan dalam akhir penyusunan laporan penelitian ini antara lain sebagai berikut :

1. Bagi Nasabah

Untuk meningkatkan jumlah kredit yang akan diberikan Bank BPR JAWA TIMUR (Bank UMKM Jawa Timur) Cabang Magetan, nasabah perlu memberikan jaminan yang lebih besar nilainya.

2. Bagi Bank

Pihak bank juga perlu menganalisis sejumlah faktor untuk mencegah terjadinya kesalahan dan mengurangi resiko yang menghambat kegiatan. Sebagai bahan masukan kepada Bank BPR JAWA TIMUR (Bank UMKM Jawa Timur) Cabang Magetan dalam memberikan jaminan terhadap kredit.

3. Bagi Peneliti Mendatang

Bagi peneliti yang akan datang, sebaiknya mengadakan pengembangan penelitian ini yaitu dengan variabel bebas besarnya jaminan, nasabah termotivasi untuk meminjam karena pemberian kredit yang sangat besar.

\section{DAFTAR PUSTAKA}

Frianto Pandia, Elly Santi Ompusunggu, Achmad Abror.2005. Lembaga Keuangan. Jakarta. Rineka Cipta

IKIP PGRI MADIUN. 2013. Pedoman Penulisan Skripsi. Madiun: Pusat Penerbitan Kampus

Iqbal Hasan. 2004. Analisis Data Penelitian Dengan Statistik. Jakarta. Bumi Aksara.

Kasmir. 2002. Bank dan Lembaga Keuangan lainnya. Jakarta. PT Raja Grafindo.

Kasmir. 2006. Manajemen Perbankan. Jakarta. PT Raja Grafindo.

Kasmir. 2007. Dasar-dasar Perbankan. Jakarta. PT Raja Grafindo

Kasmir. 2008. Bank dan Lembaga Keuangan lainnyaedisi revisi. Jakarta. PT. Raja Grafindo.

O.P. Simorangkir. 2004. Pengantar Lembaga Keuangan Bank dan Non Bank. Bogor Selatan.

Sugiyono. 2006. Statistik untuk Penelitian. Bandung. Alfabeta.

Sugiyono. 2010. Metode Penelitian Pendidikan Pendekatan Kuantitatif, Kualitatif, $R \& D$. Bandung. Alfabeta.

Suharsimi Arikunto. 2008. Prosedur Penelitian Suatu Pendekatan Praktik. Jakarta: PT. BumiAksara.

Suharsimi Arikunto. 2010. Prosedur Penelitian Suatu Pendekatan Praktik. Jakarta: PT. Bumi Aksara

Teguh Pudjo Mulyono. 2008. Manejemen Perkreditan Bagi Bank Komersiil edisi 4.

(carapedia.com/pengertian_definisi_bank) 